\title{
Derleme
}

\section{Kök kanal ilaçları}

\section{Müzeyyen Kayataş, ${ }^{1 *}$ Rabia Figen Kaptan, ${ }^{2}$ \\ Selmin Aşçı ${ }^{3}$}

${ }^{1}$ Serbest Diş Hekimi, ${ }^{2}$ Endodonti Anabilim Dalı, Yeditepe Üniversitesi Diş Hekimliği Fakültesi, ${ }^{3}$ Endodonti Anabilim Dalı, İstanbul Üniversitesi Diş Hekimliği Fakültesi, İstanbul, Türkiye

\section{ÖZET}

Pulpa ve periapikal doku hastalıklarında bakterilerin rolü olduğu gösterilmiştir. Kök kanal tedavisinin başarısında kök kanal sisteminin bakterilerden arındırılması önemli rol oynamaktadır. Bunun sağlanabilmesi için, kök kanallarının biyomekanik şekillendirmesi, antimikrobiyal ajanlarla yıkanması ve kanal içi ilaçların uygulanması gibi aseptik tedavi yöntemlerinin bir arada kullanılması gereklidir. Kök kanal dezenfeksiyonun sağlanması için kanal içinde birçok ilaç kullanılmıştır. Bu derlemede endodontide sıklıkla kullanılan kanal içi ilaçlar anlatılmaktadır. Kök kanal enfeksiyonlarının tedavisi için kanal içinde kullanılacak en iyi ilacın belirlenebilmesi için daha fazla çalışma yapılması gerekmektedir.

Anahtar Kelimeler: Antibiyotikler; dezenfeksiyon; endodonti; kalsiyum hidroksit; klorheksidin; kök kanal tedavisi

KaynaK Göstermek İçin: Kayataş M, Kaptan RF, Aşçı S. Kök kanal ilaçları. Acta Odontol Turc 2014;31(2):106-13

[Abstract in English is at the end of the manuscript]

\section{GiRiş}

Apikal periodontitis kök kanallarının içindeki bakterilerden kaynaklanmaktadır ve kanallar şekillendirildikten sonra kök kanalı içerisinde kalan bakterilerin ortadan kaldırıması için bir takım ilaçların kullanılması önerilmiştir. ${ }^{1}$

Kök kanalları içinde kullanılan ilaçlar endodontik tedavinin önemli bir parçasıdır ve birçok yararlı etkilerinin yanı sıra istenmeyen etkileri de vardır. Burada en önemli soru yararlarının yan etkilerinin oluşturduğu riski göze almaya değip değmeyeceğidir. Bu nedenle kanal içinde kullanılan ilaçlar hakkında yeterli bilgiye sahip olunması ve kullanılacak ilacın bu bilgilerin ışığında seçilmesi önemlidir.

Makale gönderiliş tarihi: 24 Ocak 2012; Yayına kabul tarihi: 22 Ağustos 2012 *iletişim: Müzeyyen Kayataş, İmam Ramiz sok. Ilgın apt. No:13/11

Sahrayıcedit, İstanbul, Türkiye;

e-posta: muzeyyengerek@yahoo.com

\section{Kök kanal ilaçlarının endodontik tedavide kullanılma nedenleri}

Kök kanal ilaçları endodontik tedavide, kemomekanik işlemlerle kök kanal sisteminden uzaklaştırılamayan canI bakterileri elimine etmek, periradiküler enflamasyonu ve ağrıyı azaltmak, enflamatuar kök rezorpsiyonunun önüne geçmek ve geçici restorasyon kırıldığında ya da düştüğünde bariyer olarak kök kanal sisteminin yeniden enfekte olmasını önlemek amacıyla kullanılmaktadır. ${ }^{2,3}$

Kanal içi ilaçlar ideal olarak kök kanal sistemini bakterilerden arındırabilmeli, enflamasyonun önüne geçebilmeli, sert doku oluşumunu uyarabilmeli ve çevre dokularda toksik etki göstermemelidir. ${ }^{2}$ Günümüzde kanal içinde kullanılmak üzere ideal bir kök kanal ilacı bulunmamakla beraber kullanılan en popüler kanal içi ilaç kalsiyum hidroksittir. ${ }^{3,4}$ Bu derlemede endodontik tedavi sırasında kök kanallarında kullanılan ilaçlar anlatılmaktadır.

\section{Fenoller}

Fenoller $\left(\mathrm{C}_{6} \mathrm{H}_{5} \mathrm{OH}\right)$ ya da karbolik asit tıpta kullanılan en eski antimikrobiyal ajanlardan biridir. Öjenol, kafurlu monoparaklorofenol (CMCP), paraklorofenol (PCP), kafurlu paraklorofenol (CPC), metakresilasetat (Cresatin), krezol ve timol endodontide kullanılan bazı fenol türevleridir. Fenol bileşiklerinin kafurlanması toksinlerin çevre dokulara salımını yavaşlatır ve daha az toksik hale getirir. 5

Bu tip kanal içi ilaçlar buharlaşarak etki göstermeleri nedeniyle ya pulpa odasına pamuk bir peletle ya da kök kanalının içine kağıt konilere emdirilerek yerleştirilir. ${ }^{1}$ Fenolik preparatların etkileri çok uzun süre devam etmez, dolayısıyla bazı bakteriler yaşamaya ve çoğalmaya devam ederler. ${ }^{6}$ Fenoller kök kanalının içine yerleştirildiğinde periapikal dokulara ve sistemik dolaşıma katılırlar, çoğunlukla nonspesifik etki gösterirler ve mikroorganizmaların yanı sıra sağlıklı dokular üzerine de etkilidirler. In vitro çalışmalar fenol ve fenol türevlerinin çok toksik etkili olduğunu ve antibakteriyel etkinliklerinin yeterli olmadığını göstermiştir. ${ }^{6}$ Kalsiyum hidroksit ve diğer kanal içi ilaçların kullanımının artması ile klasik fenol ve türevlerinin kök kanallarında kullanımı azalmıştır. 


\section{Aldehitler}

Aldehitler toksiktirler ve fiksatif etkileri vardır. Formaldehit, formokrezol ve glutaraldehit aldehit türevi maddelerdir. Formaldehitler çok toksik, mutajenik ve karsinojenik olmalarına karşın endodontik tedavide kullanılmıştır. ${ }^{7}$

Formaldehit pulpa odasına pamuk peletle uygulandığında antimikrobiyal buhar salımı yapar. Kök kanalının içine yerleştirildiğinde periapikal dokulara ve sistemik dolaşıma katııılar. Bütün formaldehit preparatları güçlü toksinlerdir ve toksik özellikleri antimikrobiyal etkinliklerinden daha fazladır. ${ }^{7}$ Aldehitlere alternatif olarak daha düşük toksisitede daha iyi antiseptikler bulunmaktadır. Bu nedenle günümüzde kullanımları önerilmemektedir.

\section{İyot bileşikleri}

İyot, 'iyodin potasyum iyodit' (IKI) formunda çok etkili bir antiseptik solüsyondur ve doku toksisitesi çok düşüktür. Antibakteriyel etkisini buharlaşarak gösterir. ${ }^{8}$ Solüsyon; $4 \mathrm{~g}$ potasyum iyoditin (KI), $2 \mathrm{~g}$ iyot (I) ile karıştırılması ile elde edilir. Bu karışım daha sonra $94 \mathrm{ml}$ distile su içinde eritilir. Eriyik halindeki iyot aseptik bir ortam sağlanması amacıyla lastik örtünün ve diş yüzeylerinin dezenfeksiyonunda kullanılır. lyodun antimikrobiyal etkisi düşük konsantrasyonda bile hızlıdır ve bakteri hücresini proteinler, nükleotidler, yağ asitleri gibi önemli gruplara etki ederek öldürdüğü düşünülmektedir. İyot; bakteriler, mantarlar, viruslar ve sporları için öldürücüdür. İyodoforlar (iyodin taşıyıcıları) iyot bileşikleridir ve aktif serbest iyot için bir rezervuar görevi görürler. lyot bileşiklerinin en önemli dezavantajı alerji oluşturabilme potansiyelidir. $^{9}$

\section{Klorheksidin (CHX)}

Klorheksidin iki simetrik 4-klorofenil halkası ve iki biguanid grubunun bir merkezi hekzametilen zinciri ile bağlanmasından oluşan sentetik katyonik bis-guaniddir. Klorheksidinin etki alanı oldukça geniştir. Aerob ve anaerob mikroorganizmaların yanı sıra Candida türlerine karşı da etkilidir. $\mathrm{CHX}$, düşük konsantrasyonda bakteriostatik, yüksek konsantrasyonda bakterisidal etki gösterir. Bakteri sporları üzerine sporostatik etki göstererek büyümelerini ve çoğalmalarını engeller. $\mathrm{CHX}$ gram-pozitif mikroorganizmalara gram negatiflerden daha fazla etki gösterir. En az duyarlı olan gram-negatif mikroorganizma türleri Proteus, Pseudomonas, Enterobacter, Actinobacter ve Kleibsiella'dır. Alkalin ortamda asit ortamdan daha etkilidir ve etkisi sabun ve organik madde varlığında azalır. ${ }^{10}$

Klorheksidin yakın zamanda kanal içi ilaç olarak kabul edilmiştir ve \%2 jel formu önerilmiştir. Klorheksidinin dezavantajı smear tabakasına etki edememesi ve kanalda kalan dokuları sabitleştirici yani fiksatif etkisinin olmasıdır. CHX'in avantajı yanı ise antibakteriyel olmaSı ve bazı bakterilerin tutunmasını engellemesidir. ${ }^{11} \mathrm{Bu}-$ nun yanı sıra $\mathrm{CHX}$ 'in pozitif yüklü molekülleri dentin tarafından adsorbe edilir ve en az 12 hafta boyunca antimikrobiyal etkisi devam eder. ${ }^{12}$ Bu süre içinde kök kanalının yeniden enfekte olması engellenir.

CHX'in jel formu periapikal dokular üzerine düşük toksisite gösterir. Sodyum hipokloritten farklı olarak organik dokuyu çözemez ve gram-negatif bakterilerin hücre duvarında bulunan ve patojenitelerini sağlayan lipopolisakkaritleri (LPS) inaktive edemez, bu nedenle kök kanallarının mekanik şekillendirme ve temizlenmesinde birinci sırada tercih edilmemektedir. ${ }^{13}$

\section{CHX ve kalsiyum hidroksit}

Kalsiyum hidroksitin $\left[\mathrm{Ca}(\mathrm{OH})_{2}\right] \mathrm{CHX}$ ile karıştırıldığında alkalinitesi değişmez fakat $\mathrm{CHX}$ molekülleri çökelir ve böylece etkinliği azalır. $\mathrm{CHX}$ ve $\mathrm{Ca}(\mathrm{OH})_{2}$ karıştıııldığında oluşan antibakteriyel etki $\mathrm{Ca}(\mathrm{OH})_{2}$ 'nin tek başına gösterdiği etkiden daha fazla değildir. ${ }^{14}$

Haenni ve ark. ${ }^{15} \mathrm{Ca}(\mathrm{OH})_{2}$ tozu ile $\mathrm{CHX}$ karıştıııldığında ilave bir antibakteriyel etkinin oluşmadığını, CHX'in antibakteriyel etkisi azalırken, $\mathrm{Ca}(\mathrm{OH})_{2}$ 'nin antibakteriyel etkisinde azalma olmadığını göstermiştir.

\section{CHX ve koronal mikrosızıntı}

CHX'in etkisinin uzun süreli olması, koronal kısımdan kanala bakteri girişini engelleyebileceğini düşündürmektedir. Gomes ve ark. ${ }^{16}$ koronal restorasyon yapılmayan ve kanal içi ilaç olarak \%2 $\mathrm{CHX}$ jel uygulanan dişlerde rekontaminasyonun, $\mathrm{Ca}(\mathrm{OH})_{2}$ 'nin tek başına ve $\mathrm{CHX}$ ile kombine kullanılan gruplara kıyasla daha uzun süre sonra olduğunu, buna karşın IRM simanı ile kapatılan gruplarda rekontaminasyonun kanallara $\mathrm{Ca}(\mathrm{OH})_{2}$ uygulanan gruplarda daha geç olduğunu bildirmişlerdir.

\section{CHX ve sodyum hipokloritin etkileşimi}

Sodyum hipoklorit ( $\mathrm{NaOCl}$ ) ve $\mathrm{CHX}$ kombine kullanıldığında turuncu-kahverengi arası bir renk değişimine, nötral ve çözünmeyen çökeltilerin oluşmasına neden olur. Bu çökeltinin asit yapıda olan klorheksidin ile alkalen yapıdaki $\mathrm{NaOCl}$ solüsyonun birbirine teması sırasında oluşan asit-baz reaksiyonundan kaynaklandığı düşünülmektedir. Çökeltilerin kök kanal dolgusu sırasında kanal patının kök dentinine tutunmasını engellediği bildirilmiştir. ${ }^{17} \mathrm{Bu}$ çökeltilerin ve renkleşmenin engellenmesi için, kanal iki solüsyon arasında distile su ile yıkanmalıdır. Alternatif olarak kanalların $\mathrm{CHX}$ ile yıkanmadan önce kağıt konilerle kurulanabileceği de bildirilmiştir. ${ }^{10}$

\section{CHX'in sitotoksisitesi}

CHX'in belirgin bir yan etkisi yoktur ve \%0.1-2 aralığındaki $\mathrm{CHX}$ solüsyonları toksikolojik olarak güvenli bulunmuştur. Daha yüksek konsantrasyonlarda bile CHX'in 
toksisitesi çok düşüktür ve klinikte kullanılan konsatrasyonlarda CHX'in biyouyumluluğu kabul edilebilir düzeydedir. $^{18}$

\section{CHX ve alleriik reaksiyonlar}

Klorheksidin duyarlılığına nadiren raslanmaktadır. En sık rastlanan yan etki kontakt dermatittir. Bunların dışında yine nadir olarak raslanan yan etkiler; deskuamatif gingivitis, dişlerin ve dilin renk değiştirmesi ve tat almadaki bozukluklardır. ${ }^{10}$

\section{Kalsiyum Hidroksit [Ca(OH) 2 ]}

$\mathrm{Ca}(\mathrm{OH})_{2}$ 'nin endodontide kullanımı 1920 yılında Hermann tarafından tanıtımıştır. Antibakteriyel olması, doku çözücü özelliği, kök rezorpsiyonunu durdurması, tamir işlemini hızlandırması ve sert doku oluşumunu uyarması nedeniyle kullanımı önerilmektedir. ${ }^{18,19}$

\section{$\mathrm{Ca}(\mathrm{OH}) 2$ 'nin fiziksel ve kimyasal özellikleri}

Kalsiyum hidroksit, formülü $\mathrm{Ca}(\mathrm{OH})_{2}$ olan, beyaz ve kokusuz bir tozdur. Molekül ağırlığı 74.08 g/mol'dür. Suda çözünürlüğü azdır ve ısı yükseldikçe çözünürlüğü azalır. pH değeri yüksektir (12.5-12.8) ve alkolde çözünmez. Bu düşük çözünürlük özelliği klinik olarak iyi bir özelliktir, çünkü bu sayede canlı dokulara doğrudan temas ettiğinde ve doku sıvıları içinde çözünmesi uzun zaman alır. ${ }^{18}$

\section{$\mathrm{Ca}(\mathrm{OH})_{2}$ 'nin biyolojik özellikleri}

Suda çözünürlüğünün az olması ve difüzyonunun sınırIı olması nedeniyle biyolojik olarak uyumludur. Enfekte kök kanallı dişlerin etrafında periapikal sert doku oluşumunu uyarır. Kök rezorpsiyonunu durdurur ve travma sonrası periapikal iyileşmeyi uyarır.,20

\section{Etki mekanizması}

$\mathrm{Ca}(\mathrm{OH})_{2}$ etkisini $\mathrm{Ca}^{2+}$ ve $\mathrm{OH}^{-}$iyonlarının ayrışması ve yüksek pH değeri ile ortamı alkali hale getirerek gösterir. Bu iyonlar canlı dokular üzerine etki ederek ve nekrotik doku artıklarını, bakterileri ve onların yan ürünlerini çözerek sert doku oluşumunu ve antibakteriyel etkiyi uyarır. Endopatojenlerin birçoğu kalsiyum hidroksitin sağladığı alkalin ortamda yaşayamaz. ${ }^{21}$

$\mathrm{Ca}(\mathrm{OH})_{2}$ oldukça küçük bir moleküldür ve formülündeki hidroksil iyonları kök dentinine diffüze olabilir. Kalsiyum hidroksitin dentin kanalları içindeki bakterilere etki edebilmesi için dentinin içindeki hidroksil iyonunun yeterli yoğunluğa ulaşması gerekir. Dentinin tamponlama kapasitesine bağlı olarak hidroksil iyonlarınının özellikle kökün apikal 1/3'üne ulaşması ve antibakteriyel etki göstermesi zorlaşır. Ramifikasyonlar, darlıklar ve kanal düzensizlikleri içindeki mikroorganizmalar alkalin pH'yi nötralize ederek kalsiyum hidroksitin etkisinden korunurlar. Ayrıca kök kanal duvarlarında bakterilerin oluş- turduğu kolonilerin en dışında yerleşen hücreler daha derinlerde yerleşen bakterileri korur ve kalsiyum hidroksitin antibakteriyel etkisini azaltır. ${ }^{18,21}$

\section{$\mathrm{Ca}(\mathrm{OH})_{2}$ 'nin mikroorganizmalara etki etme yolları}

Kalsiyum hidroksit mikroorganizmalara kimyasal olarak; mikroorganizmaların sitoplazmik membranlarına hasar vererek, enzim aktivitesini baskılayarak, hücre metabolizmasını bozarak ve DNA replikasyonunu durdurarak gösterir. Ayrıca fiziksel olarak bariyer rolü oynar ve bakterilerin kök kanallarının içine girmesini önler. Bakterilerin büyümesi için gereken maddelere bağlanarak kalan mikroorganizmaları öldürür ve çoğalmaları için gereken yeri sınırlar. 4,20

\section{$\mathrm{Ca}(\mathrm{OH})_{2}$ 'nin kanala uygulanışı}

Kök kanallarına $\mathrm{Ca}(\mathrm{OH})_{2}$ uygulamak için kanal aletlerinin döndürülerek kullanılması, patın kanal içine enjekte edilmesi, lentülo ya da Pastinject (MicroMega, Besancon, Fransa) gibi aletlerin kullanılması gibi farklı teknikler kullanılmaktadır. Bunlardan lentülo ya da Pastinject gibi kök kanallarına pat ya da ilaç uygulamak için özel olarak üretilmiş aletlerin kullanması daha etkili sonuçlar vermiştir. Pastinject ve lentülo spiralin karşılaştırıldığı çalışmalarda Pastinject'in daha iyi sonuç verdiği gösterilmiştir. ${ }^{22,23}$ Kanal aletini döndürerek uygulamak ya da kanal içine enjekte etmek bu yöntem kadar etkili değildir. Maksimum etkinlik sağlayabilmek için pat kanal içinde çalışma boyunda, sıkı ve homojen bir şekilde uygulanmalıdır. Bunun için kanal ağızları yeterince şekillendirilmiş ve kanala düz bir giriş sağlanabiliyor olmaııdır. Kanalın apikal kısmı 25 numara ya da daha büyük numara bir eğeye kadar şekillendirilmiş olmalıdır. ${ }^{23}$

\section{$\mathrm{Ca}(\mathrm{OH})_{2}$ patının hazırlanışı}

Kalsiyum hidroksit kök kanalına kuru toz olarak ya da bir taşıyıcı ile karıştırılarak pat halinde uygulanabilir. Kalsiyum hidroksiti pat haline getirme yöntemi bileşiğin hem fiziksel ve kimyasal özelliklerini hem de kanala uygulanma şeklini ve antibakteriyel özelliklerini etkiler. Karışımın mümkün olduğunca fazla $\mathrm{Ca}(\mathrm{OH})_{2}$ partikülü içermesi için olabildiğince katı kıvamda hazırlanmalıdır. ${ }^{18}$

Esasında endodontide kullanılan kalsiyum hidroksit patı; bir toz, bir taşıyıcı ve radyoopasite sağlayıcı bir ajandan oluşur. Bu maddeler materyalin sertleşmeyen pat halini sağlamak, akıcılığını artırmak, pH'sini yükseltmek, klinik kullanımını kolaylaştırmak ve antibakteriyel etkisini artırmak için ilave edilmektedir. ${ }^{18}$

\section{Taşıyıcıların tipleri ve önemleri}

Kalsiyum hidroksit, bakterileri hidroksil iyonlarının $\left(\mathrm{OH}^{-}\right)$etkisiyle öldürmektedir. Dolayısıyla etkisi büyük oranda bu iyonların salınabilmesine bağlıdır bu da $\mathrm{Ca}(\mathrm{OH})_{2}$ 'nin karıştırıldığı taşıyıcıya göre değişmektedir. Kullanılan taşıyıcının yoğunluğu azaldıkça, iyonik ayrış- 
ma daha fazla olur. ${ }^{18} \mathrm{Bu}$ nedenle $\mathrm{Ca}(\mathrm{OH})_{2}$ ile karıştırılacak taşıyıcı büyük önem taşır ve patlar kullanılan taşıyıcının tipine göre sınıflandırılır.

Örneğin; replantasyon olgularında, hızlı bir iyon saıınımı ile pH değişikliğinin sağlanması ve replasman rezorpsiyonunun önlenmesi açısından, başlangıçta sulu bir taşıyıcı ile karıştırılmış kalsiyum hidroksit uygulanmalıdır. Bundan sonraki periodlarda $\mathrm{Ca}(\mathrm{OH})_{2}$ patı kök kanallarında daha uzun süre kalabilmesi için viskoz bir taşıyıcı ile karıştırılmalıdır. Bu süre içinde $\mathrm{pH}$ seviyesi yeterli düzeyde tutulur, yavaş bir iyon salımı sağlanır ve alkalin özellikler ancak uzun bir süreçte biter. ${ }^{18}$

Kalsiyum hidroksit patı kullanılacağı zaman kalıştırıııp hazırlanacağı gibi, hazır preparatları da piyasada bulunmaktadır. Genel olarak, üç tip taşıyıcı kullanılır: Sulu, visköz ve yağlı. ${ }^{4,18}$

\section{Sulu taşıyıcılar}

Suda çözünen maddelerden oluşur. Bunlar; su, serum fizyolojik, vazokonstrüktörlü ya da vazokonstrüktörsüz anestezik solüsyon, Ringer solüsyonu, metilselülözün sulu süspansiyonu ya da karboksi metilselülöz ve aniyonik deterjan solüsyonudur. ${ }^{4,18}$

Kalsiyum hidroksit bu maddelerden biriyle karıştırıldığı zaman $\mathrm{Ca}^{2+}$ ve $\mathrm{OH}^{-}$hızlı bir şekilde salınır. Bu tip bir taşıyıcı doku ve doku sıvıları ile direkt temas ettiğinde çözünürlüğü çok yükselir ve bu da hızlıca çözünmesini ve makrofajlar tarafından rezorbe edilmesini sağlar. Kök kanalı çok kısa bir sürede boşalabilir ve iyileşme süreci ertelenir. Klinik açıdan bakıldığında istenen etki sağlanıncaya kadar kök kanalları birkaç kez açılıp yeniden $\mathrm{Ca}(\mathrm{OH})_{2}$ uygulanması gerekebilir, bu da randevu sayısını artıracaktır. ${ }^{18}$

\section{Visköz taşıyıcılar}

Bazı visköz taşıyıcılar da suda çözünen maddelerdir. Bu taşıcıların moleküler ağırlıkları artıkça $\mathrm{Ca}^{2+}$ ve $\mathrm{OH}^{-}$iyonları daha yavaş ve daha uzun sürede çözünür ve $\mathrm{Ca}(\mathrm{OH})_{2}$ dokulara daha az yayılır. Kalsiyum hidroksit istenilen bölgede daha uzun süre kalır, bu durum patın etkinliğini artırır. Kanalda 2-4 ay gibi bir süre kalabildikleri için randevu sayısı ve yeniden kalsiyum hidroksit uygulama seansları belirgin oranda azalır. Visköz taşıyıcılardan bazıları gliserin, polietilenglikol ve propilen glikoldür. ${ }^{18}$

\section{Yağlı taşıyıcılar}

Yağlı taşıyıcılar suda çözünmeyen maddelerdir. Çözünürlükleri ve dokulara yayılma miktarı azdır. Bu tip bir taşıyıcı ile karıştırılan patlar kök kanalı içinde sulu ya da visköz taşıyıcılarla karıştırılmış patlardan daha uzun süre kalırlar. Yağlı taşıcılarından bazıları zeytin yağı, silikon yağı, kafur (kafurlu paraklorofenol yağı), metakresilasetat ve oleik, linoleik ve isostearik asit gibi bazı yağ asitleridir. ${ }^{19}$

\section{Radyografik kontrast madde}

Kalsiyum hidroksit bahsedilen taşıyıcılardan herhangi biri ile karıştırıldığında radyoopasitesini kaybeder ve radyografide kolaylıkla görülemez. Bu durum patın içine radyoopak maddelerin katılmasının esas nedenidir. Böylece lateral ve yan kanallar, rezorpsiyon defektleri, kırıklar ve diğer yapılar görülebilir. Radyoopaklaştırıcıların işlevlerini görebilmeleri için atom ağırlıklarının kalsiyumdan daha fazla olması gerekir. Bu maddelerden bazıları baryum sülfat, bizmut, iodine ve bromine içeren diğer bileşiklerdir ${ }^{18}$.

\section{$\mathrm{Ca}(\mathrm{OH})_{2}$ kombinasyonları}

Endodontik enfeksiyonlar polimikrobiyaldir ve hiçbir kanal içi ilaç kök kanallarındaki tüm mikroorganizmalara etkili değildir. Kalsiyum hidroksitin dentin kanalları içindeki etkinliğini artırmak için kanal içinde kullanılan diğer ilaçlarla karıştırılması yoluna gidilmiştir. Bu maddeler suda değişik oranlarda çözünürler ve ideal olarak $\mathrm{Ca}(\mathrm{OH})_{2}$ 'nin pH'sini değiştirmemelidirler ${ }^{4}$.

$\mathrm{Bu}$ amaçla hazırlanan karışımlardan biri $\mathrm{Ca}(\mathrm{OH})_{2}$ /iyodin potasyum iyodit (IKI) karışımıdır. Kalsiyum hidroksitten farklı olarak IKI, dentin tubulleri içine diffuze olabilir ve in vivo şartlarda bakterileri öldürebilir. Ancak antimikrobiyal etkinliği kısadır. IKI ve $\mathrm{Ca}(\mathrm{OH})_{2}$ kombinasyonu, kök kanallarını $\mathrm{Ca}(\mathrm{OH})_{2}$ 'nin tek başına kullanıldığından daha etkili şekilde dezenfekte etmektedir. ${ }^{9}$

Fenol bileşiklerinin bazı özellikleri örneğin düşük yüzey gerilimi ve yağda çözünebilmesi, penetrasyon özelliğini etkiler ve kanal içine uygulanan ilacın daha kolay yayılmasını sağlar. Bu nedenle $\mathrm{Ca}(\mathrm{OH})_{2} / \mathrm{CMCP}$ karışımının etkinliği oldukça iyidir ve uygulandığı yerden daha uzak alanlardaki bakteriler üzerine de etkisini gösterir. ${ }^{4}$

Kortikosteroidler endodontide enflamasyonun azaltılması, pulpanın canlıı̆̆ının ve bütünlüğünün korunması amacıyla kullanıımıştır. ${ }^{24}$ Kök kanalı ilacı olarak $\mathrm{Ca}(\mathrm{OH})_{2}$ ve kortikosteroid-antibiyotik kombinasyonu da kullanılmıştır. Bu karışımların aktif maddelerin diffuzyonunu yavaşlattığı ve böylece kanal içi konsantrasyonu artırdığı bildirilmiştir. Buna ek olarak antibakteriyel etki artmakta ve periradikular doku toksisitesi azalmaktadır. ${ }^{25}$

Kalsiyum hidroksitin bir kortikosteroid-antibiyotik karışımı olan Ledermix ile karıştırılması oldukça popüler bir kombinasyondur. Klinik olarak direkt pulpa kuafajı, pulpotomi, rutin kanal dolgu maddesi ve apeksifikasyon işlemlerinde ve geniş periapikal lezyonların tedavisinde kullanılmaktadır. ${ }^{26}$

Kalsiyum hidroksit seanslar arasında uygulandığında periodontitisli dişlerde ağrının dindirilmesi üzerinde bir etkisi olmadığı bildirilmiştir. ${ }^{27}$ Kalsiyum hidroksit özel- 
likle periapikal lezyonlu dişlerin iyileşmesinde etkili olmaktadır. Periodontitisli dişlerde kalsiyum hidroksit kullanılarak ve iki seansta yapılan kanal tedavileri tek seansta yapılan ya da kanallar boş bırakılarak iki seansta yapılan kanal tedavilerinden daha başarılı bulunmuştur. $^{28}$

\section{$\mathrm{Ca}(\mathrm{OH})_{2}$ 'nin kanaldan uzaklaştırılması}

Kalsiyum hidroksitin kanaldan çıkarılması özellikle de apikal bölgede tam bir temizliğin sağlanması güçtür. Kalsiyum hidroksiti kanaldan çıkarmak için bir numara büyük kanal aletiyle kanalların şekillendirilmesinin yeterli olmadığı ve bu sırada kanaldan taşan $\mathrm{Ca}(\mathrm{OH})_{2}$ 'nin iyileşme üzerine olumsuz etkisi olmadığı bildirilmiştir ${ }^{29}$. Başka bir çalışmada ise $\mathrm{Ca}(\mathrm{OH})_{2}$ 'yi kanaldan çıkarmak için şekillendirmenin etilendiamintetraasetik asit (EDTA) ve $\mathrm{NaOCl}$ eşliğinde yapılması gerektiği, bu durumda daimi kanal dolgu patının dentin kanallarına daha iyi penetre olduğu gösterilmiştir. ${ }^{30}$

\section{Kortikosteroidler}

Kortikosteroidler antienflamatuar ajanlardır ve kanal içinde enflamasyonu baskılayarak postoperatif ağrıyı azalttığı iddia edilmektedir. Topikal kortikosteroidler endodontide antienflematuar ajan olarak uzun yıllardır kullanılmaktadır. Çalışmalar kortikosteroidlerin vital pulpalı dişlerde ağrının azalmasında etkili iken nekrotik pulpalı dişlerde etkisiz olduğunu göstermiştir. Bu nedenle kortikosteroidlerin nekrotik pulpalı dişlerde kullanımı önerilmemektedir. ${ }^{6}$

Kortikosteroidler antienflamatuar ajanlardır ve kanal içinde enflamasyonu baskılayarak postoperatif ağrıyı azalttığı iddia edilmektedir. Bunun yanı sıra kortikosteroidler düşük seviyedeki ağrıyı azaltabilse de daha fazla ağrılı olgularda etki gösterememektedir. En etkili olduğu klinik durumlar akut apikal periodontitis ve irreverzibl pulpitistir. ${ }^{31}$

\section{Antibiyotikler}

Endodontide antibiyotikler lokal ya da sistemik olarak kullanılırlar. ${ }^{32}$ Sistemik kullanımda allerjik reaksiyonlar, toksisite ve mikrooganizmaların dirençli türlerinin gelişmesi gibi bir takım etkiler ortaya çıkabilir. Buna ek olarak antibiyotikler sistemik kullanıldığında, hastanın doz ayarlamasına uyması önemlidir. Sistemik alınan antibiyotiğin etkili olabilmesi için etki etmesi istenen bölgede normal kan dolaşımının olması gereklidir, bu durum nekroze pulpalı dişler ve pulpasız dişler için mümkün değildir. Bu nedenle endodontide, antibiyotiklerin lokal kullanımı daha etkili olmaktadır. ${ }^{33}$

Endodontide antibiyotiklerin lokal kullanımı ilk kez 1951 yılında Grossman tarafından bildirilmiştir. Araştırmacı PBSC olarak bilinen lokal bir poliantibiyotik patını kullanmıştır. ${ }^{34}$ PBSC, gram pozitif mikroorganizmalara etki edebilmesi için Penisilin, penisiline dirençli mikroorganizmalar için Basitrasin, gram-negatif mikroorganizmalara etki edebilmesi için Streptomisin ve mantarlar için Caprylate sodyum içermektedir. Bütün bu bileşikler silikon bir taşıyıcı içinde karıştırılmıştır. Daha sonra caprylate sodyumun yerine antifungal ajan olarak Nistatin konulmuştur ve PBSN olarak bilinen kanal içi ilaç elde edilmiştir. ${ }^{35} 1975$ yılında American Food and Drug organizasyonu PBSC'nin kullanımını içeriğindeki penisiline karşı hassasiyet ve alerjik reaksiyon riski nedeniyle yasaklamıştır.

Antibiyotiklerin ticari preparatları ya tek bir antibiyotiği ya antibiyotik kombinasyonlarını ya da kortikosteroidler gibi başka maddelerle yaptıkları bileşikleri içerir. Antibiyotik ve kortikosteroid içeren patlar piyasada hazır halde bulunur. Bunlardan en sık kullanılanları Septomixine Forte (Septodont, Saint-Maur-des-Fossés, Fransa), Pulpomixine (Septodont) ve Ledermix (Lederle Pharmaceutical, Wolfrathausen, Almanya) patıdır. Her üç preparat da antienflamatuar ajan olarak kortikosteroid içerir. ${ }^{6}$

\section{Septomixine Forte}

Septomixine Forte iki antibiyotik içermektedir. Bunlar neomisin ve polimiksin B sülfat'tır. Her iki antibiyotik de etki spektrumlarının uygun olmaması nedeniyle endodontide sıklıkla rastlanan mikroorganizmalar üzerine etkili değildir. ${ }^{36}$ Tang ve ark. ${ }^{20}$ Polimiksin B sülfatın gram-pozitif bakterilere karşı etkili olmadığını göstermiştir. Araştırıcı ayrıca Septomixine Forte'nin 1 haftalık seanslarda rutin uygulamasının kanal içinde kalan bakterilerin eliminasyonunda etkili olmadığını bildirmiştir.

\section{Tetrasiklinler}

$\mathrm{Bu}$ grupta tetrasiklin $\mathrm{HCl}$, minosiklin, demeklosiklin ve doksisiklin bulunmaktadır. Büyük bir mikroorganizma grubuna etki edebilen geniş spektrumlu antibiyotiklerdir. Mantarların tetrasiklinlere karşı dirençli olduğu bilinmektedir. Tetrasiklinler bakteriostatik etkilidirler ve antimikrobiyal özelliklerinin yanı sıra doku yıkımının önlenmesi, rezorpsiyon önleyici aktiviteyi sağlamak gibi özelliklere de sahiptirler. , $^{2,37,38}$

Endodontide tetrasiklinler şekillendirilmiş kök kanallarından smear tabakasının uzaklaştırılmasında, periapikal cerrahi işlemlerinde kök ucu kavitelerinin irrigasyonu amacıyla ve kanal içi ilaç olarak kullanılmış$\operatorname{tır}^{39,40}$

\section{Tetrasiklinlerin etkisinin sürekliliği}

Tetrasiklinler bivalent ve trivalent katyonlarla bileşikler oluşturur ve antimikrobiyal etkinin sürekliliğini sağlayacak bir seviyeye ulaşırlar. Bu nedenle kalsifikasyon süresince dişlerde ve kemiklerde depolanırlar. Sert dokularla güçlü ve reverzibl bir bağ oluşturmaları ve 
dentine bağlanmaları sayesinde antibakteriyel etkilerini kaybetmeden uzun bir süre yavaş salınmaya devam ederler ve en az 12 hafta boyunca dentine diffüze olurlar. ${ }^{41}$

\section{Ledermix patı}

Ledermix patı 1960 yılında Schroeder ve Triadan tarafından geliştirilmiş bir glukokortikosteroid-antibiyotik bileşiğidir. Pat geliştirilirken esas üzerinde durulan konu ağrı ve enflamasyon kontrolünü sağlayabilmek için kortikosteroidler kullanılırken, antimikrobiyal özelliklerin Asphalin denen formalin patı ile sağlanmasıdır.,38 Üretici firma aktif madde olarak kortikosteroid kullanmış, antibiyotiği dezenfeksiyon sağlaması için değil kortikosteroid nedeniyle immün direnç geliştiğinde mikroorganizmaların büyümesini engellemek ve kortikoide bağlı olarak konak savunma cevabı azaldığında bu durumu kompanse etmek amacıyla kullanmıştır. Günümüzde Ledermix, polietilen glikol bir baz içerisinde tetrasiklin antibiyotik, demeklosiklin $\mathrm{HCl}$ (\%3.2 konsantrasyonda) ve bir kortikosteroid, triamsinolon asetonidden (\%1 konsantrasyonda) oluşmaktadır. ${ }^{3}$

Ledermix dentin kanalları ve semente diffüze olabilir ve periodontal ve periapikal dokulara ulaşabilir. Periodontal dokular üzerinde hasar oluşturmaması nedeniyle travma geçirmiş dişlerde, replantasyondan sonra ve enflamatuar kök rezorpsiyonunun tedavisinde etkili bir kanal içi ilaçtır. ${ }^{2,3}$ Her ne kadar bu fikre tüm otoriteler katılmasa da rezorpsiyonu azaltması konusundaki yararlı etkileri Bryson ve ark. ${ }^{37}$ tarafından köpek dişlerinde gösterilmiştir.

Triamsinolon dentinin tamponlama kapasitesine bağlı olarak periodontal dokulara yavaş salınır, bu da terapotik etkisinin uzun sürmesini sağlar. ${ }^{41}$ Ehrmann ve ark. ${ }^{27}$ Ledermix patının post-operatif ağrının tamponlanmasında $\mathrm{Ca}(\mathrm{OH})_{2}$ 'den daha etkili olduğunu bulmuşlardır ve bu bulgu başka birçok çalışmayla da desteklenmiştir. ${ }^{42}$

Kim ve ark. ${ }^{43}$ güneş ışığının Ledermix uygulanan dişlerde koyu gri-kahverengi renkleşmeye neden olduğunu bildirmişlerdir. Araştırmacılar Ledermix'in gingival sınırın altında yerleştirilmesini böylece renkleşmenin en aza indirilebileceğini bildirmişlerdir.

\section{Klindamisin}

Klindamisin; Actinomyces, Eubacterium, Fusobacterium, Propionobacterium, microaerophilic Streptococci, Peptococcus, Peptostreptococcus, Veillonella, Prevotella ve Porphyromonas gibi endodontide sıklıkla raslanan patojenlerin birçoğuna etkili olmasına rağmen, ${ }^{33}$ yeni yapılan bir çalışmada kök kanallarında klindamisin kullanılmasının $\mathrm{Ca}(\mathrm{OH})_{2}$ gibi geleneksel kanal içi ilaçlara oranla daha etkili olmadığı bildirilmiştir. ${ }^{44}$ Bunun dışında topikal kök kanalı ajanı olarak siprofiloksasin, metronidazol ve minosiklin kullanılmasının daha başarıIı sonuçlar verdiğini bildiren çalışmalar da bulunmaktadır. ${ }^{45}$

\section{Metronidazol}

Metronidazol bir nitroimidazol bileşiğidir ve protozoalar ve anaerob bakteriler üzerine geniş spektrumlu bir etki alanları vardır. Anaerob kokların yanı sıra gram-negatif ve gram-pozitif basillere olan etkisi bilindiğinden periodontal hastalıkların tedavisinde sistemik ve lokal olarak kullanılmıştır. Roche ve Yoshimori ${ }^{46}$ metronidazolün anaeroblar üzerine etkilerinin mükemmel olduğunu fakat aeroblar üzerine etki edemediklerini göstermiştir.

\section{Üçlü antibiyotik patları}

Kök kanal sistemi enfeksiyonları hem aerobik hem de anaerobik bakteri türlerini içeren polimikrobiyal enfeksiyonlardır. Kök kanal enfeksiyonlarının kompleks yapısı nedeniyle sadece tek bir antibiyotiğin kullanılması kanaldaki enfeksiyonun tedavisi için yeterli değildir. Bu nedenle bir antibiyotik kombinasyonunun kullanılması gerekir. ${ }^{32}$ Antibiyotiklerin kombine kullanılması aynı zamanda bakterilerin direnç kazanması olasılığını da azaltır. En umut verici kombinasyon metronidazol, siprofiloksasin ve minosiklinden oluşmaktadır.

Windley ve ark. ${ }^{47}$ üçlü antibiyotik patının kök gelişimi tamamlanmamış apikal periodontitisli köpek dişlerinin dezenfeksiyonunda etkili olduğu göstermişlerdir. Sato ve ark. ${ }^{48}$ bu karışımın kök kanalının derin tabakalarındaki bakterileri öldürme potansiyelini in situ olarak araştırmış ve her bir antibiyotikten $50 \mu \mathrm{g} / \mathrm{ml}$ kullanılarak hazırlanan kombinasyonun enfekte kök dentininin dezenfeksiyonunda yeterli olduğunu bildirmiştir. Takushige ve ark. ${ }^{49}$ aynı karışımı periapikal lezyonlu primer dişlerde 'lezyonun sterilizasyonu ve doku tamiri' (LSTR) üzerine etkinliğini araştırmıştır Araştırmacılar (gingival şişlik, fistül, indüklenen ve spontan ağrı, ısırdığında ağı gibi) klinik semptomların 4 olgu hariç tüm olgularda ortadan kalktığını bildirmişlerdir. İlk tedaviden sonra iyileşmeyen 4 olguya aynı tedavi prosedürü tekrar uygulandığında iyileşme sağlanmış ve tüm olgularda başarı sağlanmıştır.

Iwaya ve ark. ${ }^{50}$ bir olgu raporunda kök ucu gelişimi tamamlanmamış, enfekte pulpalı, periapikal tutulumu ve fistülü olan mandibular ikinci premolar dişin tedavisinde standart kök kanal tedavisi ve apeksifikasyon prosedürlerinin izlenmesi yerine iki antibiyotikten (metronidazol ve siprofiloksasin) oluşan bir patı kök kanalına yerleştirmiştir. Radyografik incelemede 5 ay sonra apikal kapanmanın başladığı ve antimikrobiyal protokolün tamamlandığı gözlenmiştir. Tedaviden 30 ay sonra kök dentininde kalınlaşma ve apikalde tam olarak kapanma gözlenmiştir. Bu durum genç daimi dişlerin pulpasının kök kanal boşluğu bakteriden arındırıldığında revaskülarize olabildiğini ortaya koymuştur. 
Günümüzde poliantibiyotik patları kök kanallarında enfeksiyonu ortadan kaldırması ve revaskülarizasyonu sağlaması nedeniyle üzerinde durulan ve araştırmaların yoğunlaştığı kanal içi ilaçlardır.

\section{Kanal içi ilaçların etki gösteremediği durumlar}

Bakteriler uygulanan kanal içi ilaçlara karşı direnç gösterebilir ve bakteri hücreleri kanal içi ilaçların ulaşamayacağı anatomik varyasyonlarda yerleşebilir, bunun yanı sıra bu ilaçların etkisi dokular, bakteri hücreleri ya da onların yan ürünleri tarafıdan nötralize edilebilir. Bu durumda kanal içi ilaçların etkinliği azalmaktadır. Ayrıca bu ilaçlar kök kanal sisteminde bakterilere ulaşacak ve onları öldürecek kadar yeterli süre kalmadığında ve bakteriler çevresel değişikliklerden sonra gen dizilimlerini değiştirerek ve zor koşullarda yaşayabildiklerinde kanal içine uygulanan ilaçlar yeterli etki gösterememektedir²,32.

\section{Sonuç}

Bu makalede derlenen bilgiler şu sonuçları ortaya koymaktadır: Fenoller ve aldehitler kanal içi ilaç olarak önemini artık yitirmiştir. Klorheksidinin jel formunun kanal içi ilaç olarak kullanımı umut vericidir ancak üzerine daha fazla çalışma yapılması gerekmektedir. Kalsiyum hidroksit günümüzde en sık kullanılan kanal içi ilaç olmasına karşın tüm enfekte kanallı dişlerde özellikle de eski kanal tedavilerinin tekrarlandığı olgularda etkisiz kalabilmektedir. Antibiyotikli patların kök kanallarındaki etkinliği yeterli değildir ve kortikosteroidlerle birlikte kullanıldıklarında esas amaç enfeksiyonun kontrolü değil ağrının dindirilmesi olmalıdır. Ledermix patının yararııı̆ı üzerinde daha fazla çalışma yapılmalıdır. Poliantibiyotik patları rejeneratif endodontide umut verici ajanlar olup etkinliği hakkında daha fazla araştırma yapııması gerekmektedir.

Çıkar çatışması: Yazarlar bu çalışmayla ilgili herhangi bir çıkar çatı̧̧malarının bulunmadığını bildirmişlerdir.

\section{KAYNAKLAR}

1. Spangberg LSW, Haapasalo M. Rationale and efficacy of root canal medicaments and root filling materials with the emphasis on treatment outcome. Endod Topics 2002;2: 35-58.

2. Abbott PV. Medicaments: aids to success in endodontics. Part 1. A review of the literature. Aust Dent J 1990;35:438-48.

3. Athanassiadis B, Abbott PV, Walsh LJ. The use of calcium hydroxide, antibiotics and biocides as antimicrobial medicaments in endodontics. Aust Dent J 2007;52:S64-82.

4. Siqueira JF Jr, Lopes HP. Mechanisms of antimicrobial activity of calcium hydroxide: a critical review. Int Endod J 1999;32:361-9.

5. Walton RE. Intracanal medicaments. Dent Clin North Am 1984;28:783-96.

6. Messer HH, Chen RS. The duration of effectiveness of root canal medicaments. J Endod 1984;10:240-5.

7. Lewis BB, Chestner SB. Formaldehyde in dentistry: a review of mutagenic and carcinogenic potential. J Am Dent Assoc 1981;103:429-34.
8. Haapasalo M, Endal U, Zandi H, Coil JM. Eradication of endodontic infection by instrumentation and irrigation solutions. Endod Topics 2005;10:77-102.

9. Molander A, Reit C, Dahlén G. The antimicrobial effect of calcium hydroxide in root canals pretreated with $5 \%$ iodine potassium iodide. Endod Dent Traumatol 1999;15:205-9.

10. Mohammadi Z, Abbott PV. The properties and applications of chlorhexidine in endodontics. Int Endod J 2009;42:288-302.

11. Grenier D. Effect of chlorhexidine on the adherence properties of Porphyromonas gingivalis. J Clin Periodontol 1996;23:140-2.

12. Rosenthal S, Spångberg L, Safavi K. Chlorhexidine substantivity in root canal dentin. Oral Surg Oral Med Oral Pathol Oral Radiol Endod 2004;98:488-92.

13. Tanomaru JM, Leonardo MR, Tanomaru Filho M, Bonetti Filho I, Silva LA. Effect of different irrigation solutions and calcium hydroxide on bacterial LPS. Int Endod J 2003;36:733-9.

14. Zerella JA, Fouad AF, Spångberg LS. Effectiveness of a calcium hydroxide and chlorhexidine digluconate mixture as disinfectant during retreatment of failed endodontic cases. Oral Surg Oral Med Oral Pathol Oral Radiol Endod 2005;100:756-61.

15. Haenni S, Schmidlin PR, Mueller B, Sener B, Zehnder M. Chemical and antimicrobial properties of calcium hydroxide mixed with irrigating solutions. Int Endod J 2003;36:100-5.

16. Gomes BP, Sato E, Ferraz CC, Teixeira FB, Zaia AA, Souza-Filho FJ. Evaluation of time required for recontamination of coronally sealed canals medicated with calcium hydroxide and chlorhexidine. Int Endod J 2003;36:604-9.

17. Basrani BR, Manek S, Sodhi RN, Fillery E, Manzur A. Interaction between sodium hypochlorite and chlorhexidine gluconate. J Endod 2007;33:966-9.

18. Fava LR, Saunders WP. Calcium hydroxide pastes: classification and clinical indications. Int Endod J 1999;32:257-82.

19. Bystrom A, Claesson R, Sundqvist G. The antibacterial effect of camphorated paramonochlorophenol, camphorated phenol and calcium hydroxide in the treatment of infected root canals. Endod Dent Traumatol 1985;1:170-5.

20. Tang G, Samaranayake LP, Yip HK. Molecular evaluation of residual endodontic microorganisms after instrumentation, irrigation and medication with either calcium hydroxide or Septomixine. Oral Dis 2004; 10:389-97.

21. Heithersay GS. Calcium hydroxide in the treatment of pulpless teeth with associated pathology. J Br Endod Soc 1975;8:74-93.

22. Deveaux E, Dufour D, Boniface B. Five methods of calcium hydroxide intracanal placement: an in vitro evaluation. Oral Surg Oral Med Oral Pathol Oral Radiol Endod 2000;89:349-55.

23. Sigurdsson A, Stancill R, Madison S. Intracanal placement of $\mathrm{Ca}(\mathrm{OH}) 2$ : a comparison of techniques. J Endod 1992;18:367-70.

24. Lawson BF, Mitchell DF. Pharmacologic treatment of painful Pulpitis. A preliminary, controlled, double-blind study. Oral Surg Oral Med Oral Pathol 1964;17:47-61.

25. Abbott PV, Hume WR, Heithersay GS. Effects of combining Ledermix and calcium hydroxide pastes on the diffusion of corticosteroid and tetracycline through human tooth roots in vitro. Endod Dent Traumatol 1989;5:188-92.

26. Santini A. Long-term clinical assessment of pulpotomies with calcium hydroxide containing Ledermix in human permanent premolars and molars. Acta Odontol Pediatr 1986;7:45-50.

27. Ehrmann EH, Messer HH, Adams GG. The relationship of intracanal medicaments to postoperative pain in endodontics. Int Endod $J$ 2003;36:868-75.

28. Trope M, Delano EO, Orstavik D. Endodontic treatment of teeth with apical periodontitis: single vs. multivisit treatment. J Endod 1999;25:34550.

29. Porkaew P, Retief DH, Barfield RD, Lacefield WR, Soong SJ. Effects of calcium hydroxide paste as an intracanal medicament on apical seal. J Endod 1990;16:369-74.

30. Calt S, Serper A. Dentinal tubule penetration of root canal sealers after root canal dressing with calcium hydroxide. J Endod 1999;25:4313. 
31. Mohammadi Z. Systemic and local applications of steroids in endodontics: an update review. Int Dent J 2009;59:297-304.

32. Mohammadi Z, Abbott PV. On the local applications of antibiotics and antibiotic-based agents in endodontics and dental traumatology. Int Endod J 2009;42:555-67.

33. Gilad JZ, Teles R, Goodson M, White RR, Stashenko P. Development of a clindamycin-impregnated fiber as an intracanal medication in endodontic therapy. J Endod 1999;25:722-7.

34. Grossman LI. Polyantibiotic treatment of pulpless teeth. J Am Dent Assoc 1951;43:265-78.

35. Grieve AR, Friend LA, Plant CG. A clinical trial of three root canal medicaments. Br Dent J 1973;134:188-93.

36. Abbott PV, Hume WR, Pearman JW. Antibiotics and endodontics. Aust Dent J 1990;35:50-60.

37. Bryson EC, Levin L, Banchs F, Abbott PV, Trope M. Effect of immediate intracanal placement of Ledermix Paste(R) on healing of replanted dog teeth after extended dry times. Dent Traumatol 2002;18:316-21.

38. Ehrmann EH. THE effect of triamcinolone with tetracycline on the dental pulp and apical periodontium. J Prosthet Dent 1965;15:144-52.

39. Barkhordar RA, Watanabe LG, Marshall GW, Hussain MZ. Removal of intracanal smear by doxycycline in vitro. Oral Surg Oral Med Oral Pathol Oral Radiol Endod 1997;84:420-3.

40. Haznedaroğlu F, Ersev $\mathrm{H}$. Tetracycline $\mathrm{HCl}$ solution as a root canal irrigant. J Endod 2001;27:738-40.

41. Abbott PV, Heithersay GS, Hume WR. Release and diffusion through human tooth roots in vitro of corticosteroid and tetracycline trace molecules from Ledermix paste. Endod Dent Traumatol 1988;4:55-62.

42. Matthews RW, Peak JD, Scully $C$. The efficacy of management of acute dental pain. Br Dent J 1994;176:413-6.

43. Kim ST, Abbott PV, McGinley P. The effects of Ledermix paste on discolouration of immature teeth. Int Endod J 2000;33:233-7.

44. Molander A, Reit C, Dahlén G. Microbiological evaluation of clindamycin as a root canal dressing in teeth with apical periodontitis. In Endod J 1990;23:113-8

45. Hoshino E, Kurihara-Ando N, Sato I, Uematsu H, Sato M, Kota K, et al. In-vitro antibacterial susceptibility of bacteria taken from infected root dentine to a mixture of ciprofloxacin, metronidazole and minocycline. Int Endod J 1996;29:125-30.
46. Roche $\mathrm{Y}$, Yoshimori RN. In-vitro activity of spiramycin and metronidazole alone or in combination against clinical isolates from odontogenic abscesses. J Antimicrob Chemother 1997;40:353-7.

47. Windley W 3rd, Teixeira F, Levin L, Sigurdsson A, Trope M. Disinfection of immature teeth with a triple antibiotic paste. J Endod 2005;31:439-43.

48. Sato I, Ando-Kurihara N, Kota K, Iwaku M, Hoshino E. Sterilization of infected root-canal dentine by topical application of a mixture of ciprofloxacin, metronidazole and minocycline in situ. Int Endod $\mathrm{J}$ 1996;29:118-24

49. Takushige T, Cruz EV, Asgor Moral A, Hoshino E. Endodontic treatment of primary teeth using a combination of antibacterial drugs. Int Endod J 2004;37:132-8.

50. Iwaya SI, Ikawa M, Kubota M. Revascularization of an immature permanent tooth with apical periodontitis and sinus tract. Dent Traumatol 2001;17:185-7.

\section{Root canal medicaments}

\section{ABStRACT}

Bacteria have been implicated in the pathogenesis and progression of pulpal and periapical diseases. The success of root canal treatment largely depends on bacterial elimination from the root canal system. This can be achieved by using combination of aseptic treatment techniques, biomechanical preparation of the root canal, irrigation with antimicrobial solutions and use of intracanal medicaments. Various medicaments have been used to achieve disinfection of the root canal system. This review deals with medicaments commonly used in endodontics. Further research is required to determine the best medicament to be used in the treatment of root canal infections.

KEYWORDS: Antibiotics; calcium hydroxide; chlorhexidine; disinfection; endodontics; root canal therapy 